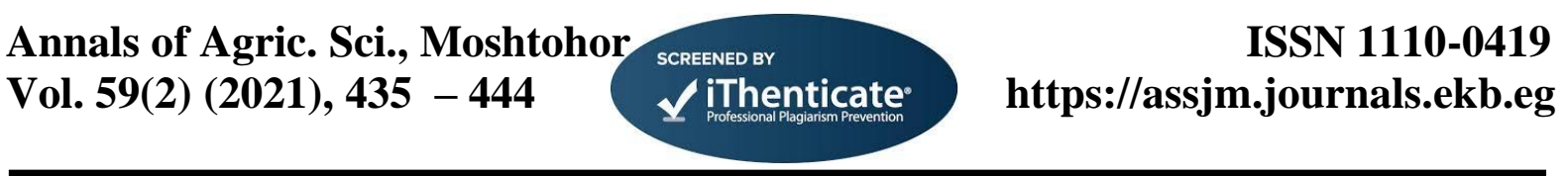

\title{
Effect of Flock Age, Air Pressure and Litter Types on Carcass Traits and Meat Quality of Broiler Chicks
}

\author{
Okasha, H.M.A ${ }^{1 *}$; El-Gendi, ${ }^{2}$ G. M and El Garhy, O.H.M ${ }^{3}$ \\ 1,2 and 3 Animal prod. dept., Faculty of Agriculture, Benha University \\ Corresponding Author: Hamada.okasha@fagr.bu.edu.eg
}

\begin{abstract}
The present study was aimed to investigate the effect of flock age (younger breeder flock 33 WKS and older breeder flock 43 WKS), air pressure during incubation period (low, 100719 (LAP) and high, 101000 (HAP) Pascal) and the type of litter on carcass characteristics and meat quality of broiler chicks. A total number of 600 one day old chicks (Ross 308) hatched from eggs of two flocks in different age (each of 300 chicks) were randomly chosen divided into two sub experimental groups according the air pressure of incubation conditions (each of 150 chicks), each sub-group divided into three sub-sub experimental groups were raised on floor house provided with litters of wood shaving, plastic and sand, respectively. This study was design as $2 \times 2 \times 3$ factorial arrangement experiment. The results obtained showed that, broiler chicks produced from older breeder flock recorded the higher significant ( $\mathrm{p}>0.05)$ absolute and relative weights of eviscerated carcass, giblets, total edible parts, protein, ash percentages, odor, color, elasticity and overall score of meat quality compared with younger ones. However broiler chicks produced from eggs incubated at HAP shoed the higher absolute and relative weights of eviscerated carcass, giblets, total edible parts, percentages of protein, fat $\mathrm{pH}, \mathrm{TVN}, \mathrm{TPA}$ and odor of meat. Broilers chicks raised on plastic (PL) litter type showed the higher values of absolute and relative weights of eviscerated carcass total edible parts, percentages of protein and ash, meat sensory evaluation and recorded the lowest microbial count of APC bacteria in meat and cecal. According to the interaction between the studied factors, it could be concluded that the broiler chicks hatched from eggs of the flock at age of $43 \mathrm{WK}$, incubated at HAP and raised on plastic litter type $(43 \mathrm{WKS} \times \mathrm{HAP} \times \mathrm{PL})$ seemed to be adequate to achieve the favorable results.
\end{abstract}

Key words: flock age, air pressure, litter type, carcass characteristics and meat quality.

\section{Introduction}

The production of broiler chickens is the most dynamically developing part of the poultry farming sector because of the short chicken rearing time, while maintaining good quality meat and low costs associated with the production (Vissers et al., 2021). The quality of production is influenced by numerous factors that may affect production results, the proper functioning of the digestive system of chickens, the general health status of birds, and the quality of meat(Banaszak et al., 2020). All these factors are related to bird well-being (Avcılar et al., 2019, Kers et al., 2019). Poultry meat quality results from complex interactions between the genotype of the animal and its raising environment (Bihan-Duval 2004) also he reported that carcass composition varies during the fattening period in addition, (Avcilar et al., 2019) reported that the environmental conditions and genotype are the key factors affecting carcass and meat quality of broilers. Their skeletal muscles, particularly the pectoralis major and minor, are one of the main body components of broiler. In food industry, these body cuts have great importance. Their external characteristics, dietary profiles, and chemical properties are essential characteristics of these muscles (Zhao et al., 2018).
Nowadays, consumers are also more interested in the nutritional value of the foods they eat (Mir et al., 2017) the $\mathrm{pH}$ and cooking losses, along with the nutritional composition, are also some of the essential parameters of meat quality assessment that can help ensure exceptional quality and profitability of the final product. In the assessment of meat quality, the ultimate $\mathrm{pH}$ is of particular importance with regard to meat physical characteristics since it can directly influence other quality characteristics, such as parameters of meat colour and shear force (Kirmizibayrak et al., 2011). Good rearing conditions including the type of bedding material, its quality, and composition can provide greater comfort thus improving the welfare conditions of broilers (Avcilar et al., 2019). Birds are reared on floors using various forms of litter material in intensive commercial broiler production. As poultry production increases, there is also an increase in the amount of litter required by the system. Consequently, both litter control and disposal pose serious challenges to the poultry industry, and its economy is a significant factor (Taherparvar et al., 2016). The consistency of litter can be the root of environmental and management issues in the commercial poultry industry (Karamanlis et al., 2008, Garcia et al., 2010) if not properly selected or managed. In chicken industry, the quality of litter is 
not only a major concern because it affects the health and productivity of the flock (Garcês et al., 2013). However, for pathogens and potential pathogens, it can be serve as a potential reservoir and transmission vehicle. The industry is also concerned with consumer trust in the food supply chain, in addition to pursuing improved efficiency, thus supporting several studies on the benefits of various bedding materials and litter chemical treatments/amendments to reduce the existence of pathogenic bacteria and improve the production characteristics of broilers (Taherparvar et al., 2016).

Because the environmental and rearing factors significantly affect of the broiler carcass traits, meat quality and therefore microbial count, these study aimed to investigate the effect of flock age, air pressure and litter types on carcass characteristics, chemical, sensory, bacteriological examinations of meat and cecum microbiota in broilers.

\section{Materials and methods:}

The present study was carried out at the Association of Al-tanmia hatching and poultry production at El-Khanka, Qalyubia Governorate, Egypt to conduct the eggs incubation period of $21^{\text {st }}$ days, starting from $12^{\text {th }}$ July 2019. The hatched chicks were brooding and reared at Poultry Research Farm belonging to the Department of Animal Production, Faculty of Agriculture, Benha University, Egypt, during the period from $1^{\text {st }}$ August to $15^{\text {th }}$ September 2019 . The chemical analysis and microbiological studies were conducted at the laboratory of Food Analysis Center, Faculty of Veterinary Medicine belonging to Benha University. This study was aimed to evaluate the effect of flock age, air pressure during incubation period and the different litter types on carcass traits and meat quality of hatched broiler chikens.

\section{Incubation:}

Eggs of a common commercial breeder flocks (Ross 308)of broiler chicken at 33 and 43 WKS of age were collect. Then, eggs were held for approximately $72 \mathrm{~h}$ under standard conditions before being set. A total number of 19200 eggs incubated by single-stage incubation program were taken randomly and equally divided into main two groups according to the flocks age (9600 per each flock). Eggs of each flock were then subdivided into two sub groups each of 4800 according to ventilation by air pressures. Eggs of the $1^{\text {st }}$ sub group were incubated by ventilation of the normal air pressure (100719 Pascal) and considered as a control group, the $2^{\text {nd }}$ sub group was incubated by ventilation with higher air pressure (101000 Pascal). Eggs were randomly set in vertical position with the large end up on each of the $4^{\text {th }}$ middle tray levels in calibrated Pas Reform incubator (Model V6.0 SmartSet ${ }^{\mathrm{TM}}$, SmartHatch ${ }^{\mathrm{TM}}$ ); the incubator was adjusted at $99.7^{\circ} \mathrm{f}$ dry bulb with relative humidity at $55 \%$ during the first 18 days of incubation, then adjusted to $97.8^{\circ} \mathrm{f}$ of dry bulb with relative humidity at $50 \%$ during the last three days in hatcher.

\section{Birds and their management:}

A total number of 600 one day old chicks (Ross 308) hatched from eggs of two flocks in different age (each of 300 chicks) were randomly chosen divided into two sub experimental groups according the air pressure of incubation conditions (each of 150 chicks), each sub-group divided into three sub-sub experimental groups were raised on floor house provided with litters of wood shaving, plastic and sand, respectively. This study was design as $2 \times 2 \times 3$ factorial arrangement experiment. Chicks were kept under similar, standard hygienic and environmental conditions. Chicks were vaccinated against Newcastle and Gumboro diseases, Pullorum free and avian influenza according to vaccination program under the supervision of a licensed veterinarian. Wood shaving and sand litters were used at $10 \mathrm{~cm}$ depth the same as the high of plastic one. The wetting litter of wood shaving and sand were continually removed and supplied with a fresh one. Floor brooders with gas heaters were used for brooding chicks. The brooding temperature was maintained at $35^{\circ} \mathrm{C}$ during the first five days of chick's age, then decreased by $2^{\circ} \mathrm{C}$ degree weekly until the end of the $4^{\text {th }}$ week. The lighting program was $24 \mathrm{~h}$ light at the first five days of age, then decreased from 6 to 35 days of age (the end of the experimental) to 23 hours light and a 1-hour dark was applied. Feed and water were offered ad-libitum. Chicks were fed starter and grower diets. The basal diet was formulated according to the recommended requirements of NRC (1994) as shown in table (1).

\section{Parameters estimated and data collection: Slaughtering and carcass characteristics:}

Carcass characteristics for random sample of 4 birds from each treatment were performed at the end of the experimental period (5 weeks). Birds chosen randomly were deprived from feed for 16 hours before slaughtering after which they were individually weighed to the nearest gram then sloughtering by cutting the throat and the jugular veins with a sharp knife near the first neck vertebra. Birds were individually reweighed after complete bleeding. Shank and head were separated, the birds were then eviscerated and intestine, gizzard, lungs, spleen, liver, heart and all internal organs were removed. The carcass and giblets (empty gizzard, liver and heart) were separately weighed. The proportional weights to live weight of giblets, carcass and total edible parts were calculated as follows: giblets weight $(\%)=(\mathrm{GW} / \mathrm{LW}) \times 100$, edible parts $(\%)=((\mathrm{EW}+\mathrm{GW}) / \mathrm{LW}) \times 100$, whereas: $\quad \mathbf{L W}=$ live weigh, $\mathbf{E W}=$ eviscerated weigh and $\mathbf{G W}=$ giblets weight. 


\section{Meat quality traits:}

Chemical composition:

The examined samples of chicken fillets and sheish were analyzed for determination of their contents of moisture, protein, fat and ash by using the standard method recommended by Horwitz (2000) "AOAC". Keeping quality tests by determination of pH (Pearson 2006), total volatile nitrogen (TVN) was recommended by Food and Agriculture Organization FAO (1980) as follows: $\mathrm{TVN} / 100 \mathrm{~g}=$ $26.88 \times\left(2-\mathrm{T}_{1}\right)$. Where, $\mathrm{T}_{1}=$ volume of $\mathrm{NaOH}$ consumed in the titration. Thiobarbituric acid number (TBA) by Pikul et al., (1989) was applied as follow: TBA value $=\quad \mathrm{R} \quad \mathrm{x} \quad 7.8 \quad(\mathrm{mg}$ malonaldehyde $/ \mathrm{Kg})$.Where, $\mathrm{R}=$ Reading of sample against blank.

\section{Sensory evaluation:}

Sensory evaluation, the examined samples of chicken meat were analyzed for the quantification of the final sensory profile according to procedures of the World's Poultry Science Association by Mead (1987). Five trained panelists applied the proposed organoleptical method of raw chicken meat analysis. The different attributes were quantified on a rating scale from 1 to 3 . The sensorial analyzed attributes were: visual look (skin and meat color), meat consistency and elasticity and the odor.

\section{Bacteriological examination:}

Bacteriological examination preparation of samples by method of Hunt et al., (2001), Aerobic Plate according to procedures of ISO (2002) and Coliform count "MPN/g Hunt et al., (2001).

\section{Statistical analysis:}

Analysis of variance was calculated using SAS procedure guide (SAS 2004) using the following linear model:

$X_{i j h k}=\mu+F_{i}+P_{j}+L_{h}+F_{i j}+F_{i h}+P L_{j h}+F P L$ ${ }_{\mathrm{ijk}}+\mathrm{e}_{\mathrm{ijhk}}$

Whereas:

$\boldsymbol{\mu}=$ the overall mean.

$\mathbf{F}_{\mathbf{i}}=$ the effect of the $\mathrm{i}^{\text {th }}$ flock age. $(\mathrm{i}, 1-2)$

$\mathbf{P j}=$ the effect of the $\mathbf{j}^{\text {th }}$ air pressure. $(\mathbf{j}, 1-2)$

$\mathbf{L}_{\mathbf{h}}=$ the effect of $h^{\text {th }}$ litter types. (h, 1-3)

FP $i \mathrm{ij}=$ the interaction between $\mathrm{i}^{\text {th }}$ flock age and $\mathrm{j}^{\text {th }}$ air pressure. $(2 \times 2)$

$\mathbf{F L}$ ih $=$ the interaction between $\mathrm{i}^{\text {th }}$ flock age and $\mathrm{h}^{\text {th }}$ litter types. $(2 \times 3)$

$\mathbf{P L}_{\mathbf{j h}}=$ the interaction between $\mathrm{j}^{\text {th }}$ air pressure and $\mathrm{h}^{\text {th }}$ litter types. $(2 \times 3)$

FPL $_{i j h}=$ the interaction between $i^{\text {th }}$ flock age, $j^{\text {th }}$ air pressure, and $h^{\text {th }}$ litter types. $(2 \times 2 \times 3)$

$\mathbf{e}_{\mathbf{i j h k}}=$ the experimental error, accordingly zero mean and variance $=\sigma^{2} e$.

Significant differences among groups means were tested using Duncan multiple range test (Duncan 1955).

\section{Results and Discussions}

Carcass characteristics:

Data presented in Table. 2 showed the absolute and proportional weights of carcass, giblets and total edible parts of carcass for broilers chickens as affected by flock age (FA), air pressure (AP), litter type (LT) and the interaction between them. Broiler chicks produced from older breeder flock recorded significant $(\mathrm{p}>0.05)$ the higher absolute and relative weights of eviscerated carcass, giblets and total edible parts compared with those produced from younger one. There is no significant variations were found in relative weights of eviscerated carcass and total edible parts due to FA. These results agree with those reported by (Horsted et al., 2005) who found that with slow-growing chickens from New Hampshire, I 657 and Light Sussex, the yield of eviscerated carcasses in these birds has changed with age. Also Kokoszynski et al., (2016) stated that significant differences $(P<0.05)$ were found for the absolute and relative weights of carcass weights due to flock age. However, there were no significant effects of air pressure and litter type on absolute and relative weights of eviscerated carcass, giblets and total edible parts. These results agree with those reported by (Vizzier-Thaxton et al., 2010) who found that low atmosphere pressure significantly affected broiler carcass quality by reducing carcass weights and caused exsanguinated carcasses after the slaughtering. Xu et al., (2015) who found that litter type did not affected on absolute weights of giblets. Poltowicz and Doktor (2011) demonstrated that Ross 308 broiler chicken recorded only a $0.64 \%$ higher dressing percentage when it has reared on wood shaving litter type.

Chemical examination of meat:

Data obtained tabulated in Table .3 revealed that highly significant $(\mathrm{p}<0.001)$ effect was found due to FA on fat $\%$ only, while, no significant variations were found in moisture, protein and ash \%, respectively due to FA. The chemical composition of meat varies during the fattening period have been reported by (Uhlírová et al., 2018). In addition (Chang et al., 2010) found that the proportion of fat in meat was increased with age increased, there was substantially lower in the breast muscles of slowgrowing chickens than in fast-growing chickens. The results obtained disagree with those reported by Díaz et al., (2010) stated that chemical compositions of the meat were significantly influenced by the age of the Sasso T-44 and X-44 (commercial strains), they added that ash contents decreased and fat was not affected with age in T-44 and X-44 pullets. Concerning to the effect of AP on meat chemical composition, it is clearly found that there was highly significant $(\mathrm{p}<0.001)$ effect on fat $\%$ of meat only due to AP. These results disagree with those reported by (Vizzier-Thaxton et al., 2010) who found that low-atmosphere pressure has been utilized 
successfully to rearing broilers without any detrimental effect on meat quality. It was found that litter type applied had significant $(\mathrm{p}<0.001)$ effect on protein percentage in meat contents, only. These results agree with those reported by (Simsek et al., 2009) who found that the litter types affecting significantly $(\mathrm{p}<0.01$ and $\mathrm{p}<0.05)$ on meat composition including protein and fat content, respectively.Tablante et al., (2003) stated that bone and meat ash was not affected by the litter types in broiler chicken.

Concerning the effect of flock age applied on the average of chemical parameter applied in meat $(\mathrm{pH}$, TVN and TPA), it was found that the FA showed highly significant $(\mathrm{p}<0.0001)$ effect on averages of TVN and TPA of meat content (table, 4). Broiler chicks produced from younger breeder flock recorded the higher values $\mathrm{pH}, \mathrm{TVN}$ and TPA (5.78, 6.22 and $0.090 \mathrm{mg} / \mathrm{Kg}$ meat, respectively). The ultimate $\mathrm{pH}$ has great importance in the evaluation of meat quality, because it may directly affect other quality characteristics; such as meat colour parameters and shear force have been reported by (Kirmizibayrak et al., 2011). These results agreed with those reported by (Poltowicz 2012) stated that chickens age had significant effect on physicochemical properties of meat, also added that $\mathrm{pH}$ tend to be significantly higher in older chicks.Pudyszak et al., (2005) observed that a tendency towards a decrease in muscle $\mathrm{pH}$ with the age of chickens and guinea fowl, respectively.

Highly significant $(\mathrm{p}<0.0001)$ variations were found in TVN and TPA only of different experimental groups due to the air pressure, it was found that broiler chicks produced from eggs incubated at HAP had the higher values of $\mathrm{pH}$, TVN and TPA (5.74, 5.54 and $0.081 \mathrm{mg} / \mathrm{Kg}$ meat, respectively). These results disagree with those reported (Dadgar et al., 2010) who found that birds were subjected to conditions of hypoxia before slaughter resulted had higher $\mathrm{pH}$ value in meat. Battula et al., (2008) stated that the effect of LAP on broiler breast meat quality including $\mathrm{pH}$ was ranged from (5.99- 5.95).

Concerning to the effect of litter type highly significant $(\mathrm{p}<0.0001)$ effect was found on TVN and TPA. Broiler chicks reared on sand litter type recorded the highest values of $\mathrm{pH}$ (5.78), TVN (6.33 $\mathrm{mg} / \mathrm{Kg})$ and TPA $(0.110 \mathrm{mg} / \mathrm{Kg}$ meat $)$ These results obtained disagree with those reported by (Meluzzi et al., 2008) who found that litter type did not exert any important effect on meat quality of broilers.

\section{Meat sensory evaluation:}

Data presented in Table. 5 shows highly significant $(\mathrm{p}<0.0001)$ effect on averages of odor, color, elasticity and overall score values in sensory examination of broiler meat the higher values of odor (2.50), color (2.33), elasticity (2.50) and overall score (9.83) were found to be highly significant increase in broilers chicks produced from older breeder flocks than the younger ones. As a general rule, birds age may play a key role because myoglobin increases with age, shifting the meat color toward darker and redder tonalities have been reported by (Bianchi et al., 2006) also showed that the age of chickens influences the color of meat. Boni et al., (2010) who found that quail meat of varying ages varied significantly in colour and acidity.

Highly significant ( $p>0.001)$ effects on averages of aspect, odor, color, elasticity and overall score values in meat sensory examination were found due to the effect of AP (table, 5). These results agree with those reported by Dadgar et al., (2010) who found that birds subjected to conditions of hypoxia before slaughter resulted in darker-colored breast meat. And disagree with those reported by Rossaint et al., (2015) who stated that no significant difference in sensory parameters were observed for poultry samples under a high-oxygen atmosphere.

Broilers chicks raised on plastic litter type recorded the highest values of aspect (2.91), odor (3.00), color (2.33), elasticity (2.75) and overall score (11.00) for meat sensory examination. These results agreed with those reported by (Saleeva et al., 2018) who stated that litter types had significantly ( $>0.05)$ affected on broiler meat quality, they added that the meat of the broiler chickens grown on the various bedding materials was better that of the broilers grown in cages.Gandi et al., (2020) found that the results of sensory parameters revealed that aroma, taste, colour, tenderness, juiciness and acceptability were significantly $(\mathrm{p}<0.05)$ affected by broiler litter types.

\section{Meat bacteriological examination}

Data presented in Table.6 showed that broiler chicks produced form old breeder flock which recorded the lowest APC $\left(3.70 \times 10^{4} \mathrm{cfu} / \mathrm{g}\right)$ and coliform count bacteria $\left(2.56 \times 10^{3} \mathrm{cfu} / \mathrm{g}\right)$ meat samples produced from different flock age were found to be free from salmonella. These results agreed with those reported by (Northcutt et al., 2003) who found that coliforms, Campylobacter, E.coli and Salmonella. $\log _{10}$ counts for coliforms, Campylobacter, and E. coli were significantly $(\mathrm{P}<0.05)$ affected by bird age. And disagree with those reported by Williams and Macklin (2013) who stated that as birds aged, bacteria increased in number, as much as $5 \mathrm{log}$ in the case of E. coli.

No significant variations were found in (APC) bacteria and coliform count bacteria due to AP. These results may be due to that the high pressure (HP) is a non-thermal technology capable of inactivating vegetative cells of pathogenic and spoilage microorganisms, modifying enzymatic activity, reducing losses of desirable compounds, thus preserving freshness and nutritional values of foods have been reported by (Huang et al., 2014). 
Litter type showed highly significant $(\mathrm{p}<0.0001)$ effect on meat bacteriological examination, broilers chicks reared on PL and WSH showed the lowest count of APC and coliform count bacteria $\left(2.95 \times 10^{3}\right.$ and $3.30 \times 10^{2} \mathrm{cfu} / \mathrm{g}$, respectively). These results agreed with those reported by (Li et al., 2017) who found that built- up litter like wood shaving and sand litter types increasing APC and coliform count bacteria in meat of chickens. Torok et al., (2009) indicated that the welfare, performance and carcass meat quality of poultry are affected directly by litter types and quality.

\section{Cecal bacteriological examination:}

Data presented in Table.6 showed highly significant $(\mathrm{P}<0.0001)$ differences were found in (APC) bacteria had positive E.coli and negative salmonella content, cecal microbial count due to FA. Broiler chicks produced from younger breeder flock had higher APC $\left(5.66 \times 10^{10} \mathrm{cfu} / \mathrm{g}\right)$ and coliform count bacteria $\left(3.83 \times 10^{10} \mathrm{cfu} / \mathrm{g}\right)$. These results agree with those reported by (Torok et al., 2009) who stated that birds age had a significant influence on cecal microbiota composition regardless of litter material.

Significant $(p>0.01)$ variations were found in APC bacteria and coliform count bacteria due to AP. However, the higher $\left(4.88 \times 10^{10} \mathrm{cfu} / \mathrm{g}\right)$ count of APC bacteria was found in cecal of broiler chicks produced from eggs incubated at HAP. These results may be attributed to the bacterial count the intestine that was captured by feeding or from the litter these agreed with (Mead 2000) hypothesized that any beneficial dietary modulation of the intestinal environment should reflect in composition and activities of the cecal microflora.

Concerning to the effect of litter type on cecal bacterial count, it was clearly observed that litter type showed highly significant $(\mathrm{p}<0.0001)$ effects on cecal microbial content of APC and coliform bacteria. broilers chicks raised on PL and S litter type showed the lowest count of APC and coliform count bacteria $\left(2.40 \times 10^{10}\right.$ and $2.40 \times 10^{10} \mathrm{cfu} / \mathrm{g}$, respectively). These results agree with those reported by (Torok et al., 2009) who found that the cecal microbiota of chickens raised on reused litter was significantly $(\mathrm{P}<0.05)$ different from that of chickens raised on any of the other litter materials, except softwood shavings at d 28.

According to the interaction between the studied factors, it could be concluded that the interaction between $43 \mathrm{WKS} \times$ HAP $\times$ PL seemed to be adequate to achieve the favorable results.

Table 1. Ingredients and calculated analysis of the experimental diets:

\begin{tabular}{|c|c|c|}
\hline Ingredients (\%) & Starting, (0-3 wks) & Growing, (3-5 wks) \\
\hline Yellow corn, ground & 56.80 & 60.00 \\
\hline Soybean meal (44\% CP) & 31.00 & 29.00 \\
\hline Corn gluten meal $(60 \% \mathrm{CP})$ & 6.75 & 4.60 \\
\hline Vit \& Min. premix* & 0.30 & 0.30 \\
\hline Sunflower oil & 1.7 & 3.00 \\
\hline Dicalcium phosphate & 2 & 1.80 \\
\hline Limestone & 1.00 & 1.00 \\
\hline Salt & 0.30 & 0.30 \\
\hline DL-methionine & 0.05 & - \\
\hline L- lysine & 0.10 & - \\
\hline Total & 100 & 100 \\
\hline \multicolumn{3}{|l|}{ Calculated analysis** } \\
\hline Crude Protein (\%) 23.0021 .00 & 23.00 & 21.00 \\
\hline $\mathrm{ME}(\mathrm{KCal} / \mathrm{Kg}$ diet $)$ & 3000 & 3100 \\
\hline Crude fiber $(\%)$ & 3.26 & 3.51 \\
\hline Crude fat $(\%)$ & 4.28 & 5.64 \\
\hline Calcium (\%) & 0.98 & 0.93 \\
\hline Available phosphorus (\%) & 0.46 & 0.41 \\
\hline \multicolumn{3}{|c|}{$\begin{array}{l}\text { *Each diet was supplied with2.5 kg/ton Vit. \& Min. Mix (commercial source B. p. Max) Each } 3 \mathrm{~kg} \text { contains, Vit. A } \\
\text { 10,000,000 MIU, Vit. D 2000,000 MIU, Vit. E 10,000 mg, Vit, K3 } 1000 \mathrm{mg} \text {, Vit, B1 } 1000 \mathrm{mg} \text {, Vit, B2 } 5000 \mathrm{mg} \text {, Vit, B6 } \\
1500 \mathrm{mg} \text {, Biotin } 50 \mathrm{mg} \text {, BHT 10,000 mg, Pantothenic 10,000 mg, folic acid } 1000 \mathrm{mg} \text {, Nicotinic acid 30,000 mg, Mn } 60 \mathrm{gm} \text {, } \\
\text { Zinc } 50 \mathrm{gm}, \mathrm{Fe} 30 \mathrm{gm}, \mathrm{Cu} 4 \mathrm{gm}, \mathrm{I} 3 \mathrm{gm} \text {, Selenium } 0.1 \mathrm{gm} \text {, Co } 0.1 \mathrm{gm}{ }^{* *} \text { Calculated according to NRC" (1994). }\end{array}$} \\
\hline
\end{tabular}


Table 2. least_square means and standard error $(\bar{X} \pm S . E)$ for carcass characteristics of different experimental groups as affected by studied factors

\begin{tabular}{|c|c|c|c|c|c|c|c|}
\hline \multirow{3}{*}{+2} & \multirow{3}{*}{ Items } & \multicolumn{6}{|c|}{ Absolute and relative weights of carcass traits } \\
\hline & & \multirow{2}{*}{$\begin{array}{c}\text { Eviscerated } \\
\mathrm{g} \\
\end{array}$} & \multirow{2}{*}{$\frac{\text { carcass }}{\%}$} & \multicolumn{2}{|c|}{ Giblets } & \multicolumn{2}{|c|}{ Total edible parts } \\
\hline & & & & $\mathbf{g}$ & $\%$ & g & $\%$ \\
\hline \multirow{2}{*}{ FA } & 33WKS & $1780.41 \pm 21.61^{\mathrm{b}}$ & $73.54 \pm 1.24$ & $107.96 \pm 3.36^{\mathrm{b}}$ & $4.45 \pm 0.12^{\mathrm{b}}$ & $1888.38 \pm 23.08^{b}$ & $78.00 \pm 1.30$ \\
\hline & $55 \mathrm{WKS}$ & $2001.40 \pm 21.61^{\mathrm{a}}$ & $73.60 \pm 1.24$ & $143.40 \pm 3.36^{\mathrm{a}}$ & $5.26 \pm 0.12^{\mathrm{a}}$ & $2144.81 \pm 23.08^{\mathrm{a}}$ & $78.86 \pm 1.30$ \\
\hline \multirow{2}{*}{$\mathbf{A P}$} & LAP & $1862.95 \pm 21.61$ & $72.90 \pm 1.24$ & $125.40 \pm 3.36$ & $4.88 \pm 0.12$ & $1988.36 \pm 23.08$ & $77.79 \pm 1.30$ \\
\hline & HAP & $1918.86 \pm 21.61$ & $74.24 \pm 1.24$ & $125.96 \pm 3.36$ & $4.83 \pm 0.12$ & $2044.83 \pm 23.08$ & $79.07 \pm 1.30$ \\
\hline \multirow{3}{*}{$\mathbf{L T}$} & WSH & $1875.00 \pm 26.46$ & $73.41 \pm 1.52$ & $123.63 \pm 4.12$ & $4.81 \pm 0.15$ & $1998.63 \pm 28.27$ & $78.22 \pm 1.59$ \\
\hline & $\mathbf{P L}$ & $1927.25 \pm 26.46$ & $74.44 \pm 1.52$ & $126.61 \pm 4.12$ & $4.85 \pm 0.15$ & $2053.86 \pm 28.27$ & $79.30 \pm 1.59$ \\
\hline & $\mathbf{S}$ & $1870.48 \pm 26.46$ & $72.86 \pm 1.52$ & $126.80 \pm 4.12$ & $4.91 \pm 0.15$ & $1997.28 \pm 28.27$ & $77.78 \pm 1.59$ \\
\hline \multirow{12}{*}{$\mathbf{F A} \times \mathbf{A P} \times \mathbf{L T}$} & 33WKS $\times$ LAP $\times W S H$ & $1703.75 \pm 52.93^{\mathrm{e}}$ & $70.88 \pm 3.05$ & $110.97 \pm 8.25^{\mathrm{cd}}$ & $4.62 \pm 0.31^{\mathrm{ab}}$ & $1814.72 \pm 56.54^{\mathrm{f}}$ & $75.50 \pm 3.18$ \\
\hline & 33WKS $\times \mathbf{L A P} \times \mathbf{P L}$ & $1713.75 \pm 52.93^{\mathrm{e}}$ & $73.98 \pm 3.05$ & $110.23 \pm 8.25^{\mathrm{cd}}$ & $4.74 \pm 0.31^{\mathrm{ab}}$ & $1823.98 \pm 56.54^{\mathrm{f}}$ & $78.72 \pm 3.18$ \\
\hline & 33WKS $\times \mathbf{L A P} \times \mathbf{S}$ & $1783.75 \pm 52.93^{\mathrm{de}}$ & $73.23 \pm 3.05$ & $115.25 \pm 8.25^{\mathrm{bcd}}$ & $4.72 \pm 0.31^{\mathrm{ab}}$ & $1899.00 \pm 56.54^{\mathrm{ef}}$ & $77.95 \pm 3.18$ \\
\hline & $33 W K S \times H A P \times W S H$ & $1860.00 \pm 52.93^{\text {cde }}$ & $73.88 \pm 3.05$ & $100.10 \pm 8.25^{\mathrm{d}}$ & $3.96 \pm 0.31^{\mathrm{b}}$ & $1960.10 \pm 56.54^{\text {cdef }}$ & $77.84 \pm 3.18$ \\
\hline & 33WKS $\times$ HAP $\times$ PL & $1797.50 \pm 52.93^{\mathrm{de}}$ & $73.74 \pm 3.05$ & $99.21 \pm 8.25^{\mathrm{d}}$ & $4.05 \pm 0.31^{\mathrm{b}}$ & $1896.71 \pm 56.54^{\mathrm{ef}}$ & $77.79 \pm 3.18$ \\
\hline & 33WKS $\times$ HAP $\times S$ & $1823.75 \pm 52.93^{\text {cde }}$ & $75.56 \pm 3.05$ & $112.01 \pm 8.25^{\mathrm{cd}}$ & $4.63 \pm 0.31^{\mathrm{ab}}$ & $1935.76 \pm 56.54^{\text {def }}$ & $80.20 \pm 3.18$ \\
\hline & 43WKS $\times$ LAP $\times W S H$ & $1990.00 \pm 52.93^{\mathrm{bc}}$ & $75.99 \pm 3.05$ & $134.87 \pm 8.25^{\mathrm{abc}}$ & $5.12 \pm 0.31^{\mathrm{a}}$ & $2124.87 \pm 56.54^{\mathrm{bc}}$ & $81.12 \pm 3.18$ \\
\hline & 43WKS $\times L A P \times P L$ & $2039.00 \pm 52.93^{\mathrm{ab}}$ & $72.37 \pm 3.05$ & $139.96 \pm 8.25^{\mathrm{ab}}$ & $4.96 \pm 0.31^{\mathrm{ab}}$ & $2178.96 \pm 56.54^{\mathrm{ab}}$ & $77.33 \pm 3.18$ \\
\hline & 43WKS $\times \mathrm{LAP} \times \mathrm{S}$ & $1947.50 \pm 52.93^{\text {bcd }}$ & $70.96 \pm 3.05$ & $141.13 \pm 8.25^{\mathrm{ab}}$ & $5.15 \pm 0.31^{\mathrm{a}}$ & $2088.63 \pm 56.54^{\mathrm{bcd}}$ & $76.11 \pm 3.18$ \\
\hline & 43WKS $\times$ HAP $\times$ WSH & $1946.25 \pm 52.93^{\text {bcd }}$ & $72.88 \pm 3.05$ & $148.58 \pm 8.25^{\mathrm{a}}$ & $5.53 \pm 0.31^{\mathrm{a}}$ & $2094.83 \pm 56.54^{\mathrm{bcd}}$ & $78.42 \pm 3.18$ \\
\hline & 43WKS $\times$ HAP $\times P L$ & $2158.75 \pm 52.93^{\mathrm{a}}$ & $77.69 \pm 3.05$ & $157.06 \pm 8.25^{\mathrm{a}}$ & $5.65 \pm 0.31^{\mathrm{a}}$ & $2315.81 \pm 56.54^{\mathrm{a}}$ & $83.34 \pm 3.18$ \\
\hline & 43WKS $\times$ HAP $\times S$ & $1926.93 \pm 52.93^{\mathrm{bcd}}$ & $71.70 \pm 3.05$ & $138.81 \pm 8.25^{\mathrm{ab}}$ & $5.16 \pm 0.31^{\mathrm{a}}$ & $2065.75 \pm 56.54^{\text {bcde }}$ & $76.86 \pm 3.18$ \\
\hline
\end{tabular}

Mean having similar letters in each column within each factor are not significantly different.

Where; FA= flock age, $\mathrm{AP}=$ Air pressure and $\mathrm{LT}=$ litter types

Table 3. least - square means and standard error $(\bar{X} \pm S . E)$ for meet chemical examination (moisture, protein, fat and ash) of different experimental groups as affected by studied factors

\begin{tabular}{|c|c|c|c|c|c|}
\hline & Items & Moisture (\%) & Protein (\%) & Fat $(\%)$ & $\operatorname{Ash}(\%)$ \\
\hline \multirow{2}{*}{ FA } & 33WKS & $73.73 \pm 0.48$ & $19.51 \pm 0.23$ & $21.50 \pm 0.23^{\mathrm{a}}$ & $1.61 \pm 0.23$ \\
\hline & 43WKS & $73.10 \pm 0.48$ & $20.20 \pm 0.23$ & $11.50 \pm 0.23^{b}$ & $1.93 \pm 0.23$ \\
\hline \multirow{3}{*}{$\mathbf{A P}$} & LAP & $73.56 \pm 0.48$ & $19.85 \pm 0.23$ & $16.00 \pm 0.23^{\mathrm{b}}$ & $1.80 \pm 0.23$ \\
\hline & HAP & $73.26 \pm 0.48$ & $19.86 \pm 0.23$ & $17.00 \pm 0.23^{\mathrm{a}}$ & $1.75 \pm 0.23$ \\
\hline & WSH & $73.47 \pm 0.59$ & $19.90 \pm 0.28^{\mathrm{ab}}$ & $16.50 \pm 0.28$ & $1.67 \pm 0.28$ \\
\hline \multirow[t]{7}{*}{$\mathbf{L T}$} & PL & $72.97 \pm 0.59$ & $20.47 \pm 0.28^{\mathrm{a}}$ & $16.50 \pm 0.28$ & $2.02 \pm 0.28$ \\
\hline & $\mathbf{S}$ & $73.80 \pm 0.59$ & $19.20 \pm 0.28^{b}$ & $16.50 \pm 0.28$ & $1.62 \pm 0.28$ \\
\hline & 33WKS $\times$ LAP $\times$ WSH & $74.50 \pm 1.19$ & $19.40 \pm 0.57^{\mathrm{ab}}$ & $21.00 \pm 0.57^{\mathrm{b}}$ & $1.60 \pm 0.57$ \\
\hline & 33WKS $\times \mathbf{L A P} \times \mathbf{P L}$ & $73.30 \pm 1.19$ & $20.10 \pm 0.57^{\mathrm{ab}}$ & $21.00 \pm 0.57^{\mathrm{b}}$ & $1.90 \pm 0.57$ \\
\hline & $33 W K S \times L A P \times S$ & $73.70 \pm 1.19$ & $19.10 \pm 0.57^{\mathrm{ab}}$ & $21.00 \pm 0.57^{\mathrm{b}}$ & $1.70 \pm 0.57$ \\
\hline & 33WKS $\times$ HAP $\times W S H$ & $73.10 \pm 1.19$ & $19.70 \pm 0.57^{\mathrm{ab}}$ & $22.00 \pm 0.57^{\mathrm{a}}$ & $1.30 \pm 0.57$ \\
\hline & 33WKS $\times$ HAP $\times \mathbf{P L}$ & $72.90 \pm 1.19$ & $20.00 \pm 0.57^{\mathrm{ab}}$ & $22.00 \pm 0.57^{\mathrm{a}}$ & $1.80 \pm 0.57$ \\
\hline \multirow{7}{*}{$\mathbf{F A} \times \mathbf{A P} \times \mathbf{L T}$} & 33WKS $\times$ HAP $\times S$ & $74.90 \pm 1.19$ & $18.80 \pm 0.57^{\mathrm{b}}$ & $22.00 \pm 0.57^{\mathrm{a}}$ & $1.40 \pm 0.57$ \\
\hline & 43WKS $\times$ LAP $\times W S H$ & $73.40 \pm 1.19$ & $20.10 \pm 0.57^{\mathrm{ab}}$ & $11.00 \pm 0.57^{\mathrm{d}}$ & $1.70 \pm 0.57$ \\
\hline & 43WKS $\times L A P \times P L$ & $73.00 \pm 1.19$ & $20.80 \pm 0.57^{\mathrm{a}}$ & $11.00 \pm 0.57^{\mathrm{d}}$ & $2.00 \pm 0.57$ \\
\hline & 43WKS $\times L A P \times S$ & $73.50 \pm 1.19$ & $19.60 \pm 0.57^{\mathrm{ab}}$ & $11.00 \pm 0.57^{\mathrm{d}}$ & $1.90 \pm 0.57$ \\
\hline & 43WKS $\times$ HAP $\times W S H$ & $72.90 \pm 1.19$ & $20.40 \pm 0.57^{\mathrm{ab}}$ & $12.00 \pm 0.57^{\mathrm{c}}$ & $2.10 \pm 0.57$ \\
\hline & 43WKS $\times$ HAP $\times P L$ & $72.70 \pm 1.19$ & $21.00 \pm 0.57^{\mathrm{a}}$ & $12.00 \pm 0.57^{\mathrm{c}}$ & $2.40 \pm 0.57$ \\
\hline & 43WKS $\times$ HAP $\times S$ & $73.10 \pm 1.19$ & $19.30 \pm 0.57^{\mathrm{ab}}$ & $12.00 \pm 0.57^{\mathrm{c}}$ & $1.50 \pm 0.57$ \\
\hline
\end{tabular}

Where; $\mathrm{FA}=$ flock age, $\mathrm{AP}=$ Air pressure and $\mathrm{LT}=$ litter types 
Table 4. least - square means and standard error $(\bar{X} \pm S . E)$ for meet chemical examination of meat (pH, TVN, and TPA $(\mathrm{mg} / \mathrm{Kg}))$ of different experimental groups as affected by studied factors

\begin{tabular}{|c|c|c|c|c|}
\hline & Items & $\mathbf{p H}$ & TVN (mg /Kg) & TPA (mg/Kg) \\
\hline \multirow{2}{*}{ FA } & 33WKS & $5.78 \pm 0.23$ & $6.22 \pm 0.23^{\mathrm{a}}$ & $0.090 \pm 0.00^{\mathrm{a}}$ \\
\hline & 43WKS & $5.66 \pm 0.23$ & $3.86 \pm 0.23^{\mathrm{b}}$ & $0.066 \pm 0.00^{\mathrm{b}}$ \\
\hline \multirow{3}{*}{$\mathbf{A P}$} & LAP & $5.69 \pm 0.23$ & $4.55 \pm 0.23^{\mathrm{b}}$ & $0.075 \pm 0.00^{\mathrm{b}}$ \\
\hline & HAP & $5.74 \pm 0.23$ & $5.54 \pm 0.23^{\mathrm{a}}$ & $0.081 \pm 0.00^{\mathrm{a}}$ \\
\hline & WSH & $5.73 \pm 0.28$ & $5.44 \pm 0.28^{\mathrm{b}}$ & $0.082 \pm 0.00^{\mathrm{b}}$ \\
\hline \multirow[t]{7}{*}{$\mathbf{L T}$} & PL & $5.64 \pm 0.28$ & $3.37 \pm 0.28^{c}$ & $0.042 \pm 0.00^{\mathrm{c}}$ \\
\hline & $\mathbf{S}$ & $5.78 \pm 0.28$ & $6.33 \pm 0.28^{\mathrm{a}}$ & $0.110 \pm 0.00^{\mathrm{a}}$ \\
\hline & 33WKS $\times$ LAP $\times$ WSH & $5.77 \pm 0.57$ & $6.01 \pm 0.57^{\mathrm{cd}}$ & $0.090 \pm 0.00^{\mathrm{d}}$ \\
\hline & 33WKS $\times \mathbf{L A P} \times \mathbf{P L}$ & $5.67 \pm 0.57$ & $3.70 \pm 0.57^{\mathrm{ef}}$ & $0.060 \pm 0.00^{\mathrm{g}}$ \\
\hline & $33 W K S \times L A P \times S$ & $5.81 \pm 0.57$ & $6.34 \pm 0.57^{b c}$ & $0.110 \pm 0.00^{\mathrm{b}}$ \\
\hline & 33WKS $\times$ HAP $\times W S H$ & $5.83 \pm 0.57$ & $7.86 \pm 0.57^{b}$ & $0.080 \pm 0.00^{\mathrm{e}}$ \\
\hline & 33WKS $\times$ HAP $\times \mathbf{P L}$ & $5.69 \pm 0.57$ & $3.88 \pm 0.57^{\mathrm{ef}}$ & $0.060 \pm 0.00^{\mathrm{g}}$ \\
\hline \multirow{7}{*}{$\mathbf{F A} \times \mathbf{A P} \times \mathbf{L T}$} & $33 W K S \times H A P \times S$ & $5.92 \pm 0.57$ & $9.57 \pm 0.57^{\mathrm{f}}$ & $0.140 \pm 0.00^{\mathrm{a}}$ \\
\hline & 43WKS $\times$ LAP $\times$ WSH & $5.63 \pm 0.57$ & $3.85 \pm 0.57^{\mathrm{ef}}$ & $0.070 \pm 0.00^{\mathrm{f}}$ \\
\hline & 43WKS $\times L A P \times P L$ & $5.62 \pm 0.57$ & $3.13 \pm 0.57^{\mathrm{f}}$ & $0.030 \pm 0.00^{\mathrm{h}}$ \\
\hline & 43WKS $\times L A P \times S$ & $5.68 \pm 0.57$ & $4.29 \pm 0.57^{\mathrm{def}}$ & $0.090 \pm 0.00^{\mathrm{d}}$ \\
\hline & 43WKS $\times$ HAP $\times$ WSH & $5.71 \pm 0.57$ & $4.04 \pm 0.57^{\mathrm{ef}}$ & $0.090 \pm 0.00^{\mathrm{d}}$ \\
\hline & 43WKS $\times$ HAP $\times P L$ & $5.59 \pm 0.57$ & $2.78 \pm 0.57^{\mathrm{a}}$ & $0.020 \pm 0.00^{\mathrm{i}}$ \\
\hline & 43WKS $\times$ HAP $\times S$ & $5.74 \pm 0.57$ & $5.12 \pm 0.57^{\mathrm{cde}}$ & $0.100 \pm 0.00^{c}$ \\
\hline
\end{tabular}

Where; FA= flock age, $\mathrm{AP}=$ Air pressure and $\mathrm{LT}=$ litter types

Table 5. least - square means and standard error $(\bar{X} \pm S . E)$ for meat sensory evaluation (aspect, odor, color and elasticity) of different experimental groups as affected by studied factors

\begin{tabular}{|c|c|c|c|c|c|c|}
\hline & Items & $\begin{array}{c}\text { Aspect } \\
\text { (3) }\end{array}$ & $\begin{array}{c}\text { Odor } \\
\text { (3) }\end{array}$ & $\begin{array}{c}\text { Color } \\
\text { (3) }\end{array}$ & $\begin{array}{c}\text { Elasticity } \\
\text { (3) }\end{array}$ & $\begin{array}{c}\text { Overall } \\
\text { (12) }\end{array}$ \\
\hline \multirow{2}{*}{ FA } & 33WKS & $2.61 \pm 0.039^{\mathrm{a}}$ & $2.33 \pm 0.00^{\mathrm{b}}$ & $1.88 \pm 0.039^{\mathrm{b}}$ & $2.33 \pm 0.00^{\mathrm{b}}$ & $9.16 \pm 0.00^{b}$ \\
\hline & 43WKS & $2.50 \pm 0.039^{a}$ & $2.50 \pm 0.00^{\mathrm{a}}$ & $2.33 \pm 0.039^{\mathrm{a}}$ & $2.50 \pm 0.00^{\mathrm{a}}$ & $9.83 \pm 0.00^{\mathrm{a}}$ \\
\hline \multirow{3}{*}{$\mathbf{A P}$} & LAP & $2.66 \pm 0.039^{\mathrm{a}}$ & $2.33 \pm 0.00^{\mathrm{b}}$ & $2.16 \pm 0.039$ & $2.50 \pm 0.00^{\mathrm{a}}$ & $9.66 \pm 0.00^{\mathrm{a}}$ \\
\hline & HAP & $2.44 \pm 0.039^{\mathrm{b}}$ & $2.50 \pm 0.00^{\mathrm{a}}$ & $2.05 \pm 0.039$ & $2.33 \pm 0.00^{\mathrm{b}}$ & $9.33 \pm 0.00^{\mathrm{b}}$ \\
\hline & WSH & $2.25 \pm 0.048^{c}$ & $2.00 \pm 0.00^{\mathrm{c}}$ & $1.75 \pm 0.048^{b}$ & $2.50 \pm 0.00^{\mathrm{b}}$ & $8.50 \pm 0.00^{c}$ \\
\hline \multirow[t]{7}{*}{$\mathbf{L T}$} & PL & $2.91 \pm 0.048^{\mathrm{a}}$ & $3.00 \pm 0.00^{\mathrm{a}}$ & $2.33 \pm 0.048^{\mathrm{a}}$ & $2.75 \pm 0.00^{\mathrm{a}}$ & $11.00 \pm 0.00^{\mathrm{a}}$ \\
\hline & $\mathbf{S}$ & $2.50 \pm 0.048^{b}$ & $2.25 \pm 0.00^{\mathrm{b}}$ & $2.25 \pm 0.048^{\mathrm{a}}$ & $2.00 \pm 0.00^{c}$ & $9.00 \pm 0.00^{\mathrm{b}}$ \\
\hline & 33WKS $\times$ LAP $\times$ WSH & $3.00 \pm 0.096^{\mathrm{a}}$ & $2.00 \pm 0.00^{\mathrm{b}}$ & $2.00 \pm 0.096^{\mathrm{c}}$ & $2.00 \pm 0.00^{\mathrm{b}}$ & $9.00 \pm 0.00^{\mathrm{d}}$ \\
\hline & 33WKS $\times \mathbf{L A P} \times \mathbf{P L}$ & $3.00 \pm 0.096^{\mathrm{a}}$ & $3.00 \pm 0.00^{\mathrm{a}}$ & $2.00 \pm 0.096^{\mathrm{c}}$ & $2.00 \pm 0.00^{\mathrm{b}}$ & $10.00 \pm 0.00^{\mathrm{c}}$ \\
\hline & 33WKS $\times \mathbf{L A P} \times \mathbf{S}$ & $2.00 \pm 0.096^{\mathrm{c}}$ & $2.00 \pm 0.00^{\mathrm{b}}$ & $2.00 \pm 0.096^{\mathrm{c}}$ & $3.00 \pm 0.00^{\mathrm{a}}$ & $9.00 \pm 0.00^{\mathrm{d}}$ \\
\hline & 33WKS $\times$ HAP $\times W S H$ & $2.00 \pm 0.096^{\mathrm{c}}$ & $2.00 \pm 0.00^{\mathrm{b}}$ & $2.00 \pm 0.096^{\mathrm{c}}$ & $2.00 \pm 0.00^{\mathrm{b}}$ & $8.00 \pm 0.00^{\mathrm{e}}$ \\
\hline & 33WKS $\times$ HAP $\times P L$ & $2.66 \pm 0.096^{\mathrm{b}}$ & $3.00 \pm 0.00^{\mathrm{a}}$ & $2.33 \pm 0.096^{b}$ & $3.00 \pm 0.00^{\mathrm{a}}$ & $11.00 \pm 0.00^{\mathrm{b}}$ \\
\hline \multirow{7}{*}{$\mathbf{F A} \times \mathbf{A P} \times \mathbf{L T}$} & 33WKS $\times$ HAP $\times S$ & $3.00 \pm 0.096^{\mathrm{a}}$ & $2.00 \pm 0.00^{\mathrm{b}}$ & $1.00 \pm 0.096^{\mathrm{d}}$ & $2.00 \pm 0.00^{\mathrm{b}}$ & $8.00 \pm 0.00^{\mathrm{e}}$ \\
\hline & 43WKS $\times$ LAP $\times W S H$ & $3.00 \pm 0.096^{\mathrm{a}}$ & $2.00 \pm 0.00^{\mathrm{b}}$ & $3.00 \pm 0.096^{\mathrm{a}}$ & $2.00 \pm 0.00^{\mathrm{b}}$ & $10.00 \pm 0.00^{c}$ \\
\hline & 43WKS $\times L A P \times P L$ & $3.00 \pm 0.096^{\mathrm{a}}$ & $3.00 \pm 0.00^{\mathrm{a}}$ & $2.00 \pm 0.096^{\mathrm{c}}$ & $3.00 \pm 0.00^{\mathrm{a}}$ & $11.00 \pm 0.00^{\mathrm{b}}$ \\
\hline & 43WKS $\times$ LAP $\times S$ & $2.00 \pm 0.096^{c}$ & $2.00 \pm 0.00^{\mathrm{b}}$ & $2.00 \pm 0.096^{c}$ & $3.00 \pm 0.00^{\mathrm{a}}$ & $9.00 \pm 0.00^{\mathrm{d}}$ \\
\hline & 43WKS $\times$ HAP $\times W S H$ & $2.00 \pm 0.096^{\mathrm{c}}$ & $3.00 \pm 0.00^{\mathrm{a}}$ & $2.00 \pm 0.096^{\mathrm{c}}$ & $2.00 \pm 0.00^{\mathrm{b}}$ & $9.00 \pm 0.00^{\mathrm{d}}$ \\
\hline & 43WKS $\times$ HAP $\times P L$ & $3.00 \pm 0.096^{\mathrm{a}}$ & $3.00 \pm 0.00^{\mathrm{a}}$ & $3.00 \pm 0.096^{\mathrm{a}}$ & $3.00 \pm 0.00^{\mathrm{a}}$ & $12.00 \pm 0.00^{\mathrm{a}}$ \\
\hline & 43WKS $\times$ HAP $\times S$ & $2.00 \pm 0.096^{\mathrm{c}}$ & $2.00 \pm 0.00^{\mathrm{b}}$ & $2.00 \pm 0.096^{\mathrm{c}}$ & $2.00 \pm 0.00^{\mathrm{b}}$ & $8.00 \pm 0.00^{\mathrm{e}}$ \\
\hline
\end{tabular}

Where; $\mathrm{FA}=$ flock age, $\mathrm{AP}=$ Air pressure and $\mathrm{LT}=$ litter types 
Table 6. least _ square means and standard error $(\bar{X} \pm S . E)$ for cecal bacterial count (APC, Coliform count, E. coli and Salmonellae) of different experimental groups as affected by studied factors

\begin{tabular}{|c|c|c|c|c|c|}
\hline Items & & APC (cfu/g) & $\begin{array}{l}\text { Coliform } \\
\text { count }(\text { cfu/g) }\end{array}$ & E. coli & Salmonellae \\
\hline \multirow{2}{*}{ FA } & 33WKS & $5.66 \times 10^{10} \pm 0.20^{\mathrm{a}}$ & $3.38 \times 10^{10} \pm 0.21^{\mathrm{a}}$ & $+\mathrm{ve}$ & -ve \\
\hline & 43WKS & $3.15 \times 10^{10} \pm 0.20^{\mathrm{b}}$ & $3.01 \times 10^{10} \pm 0.21^{\mathrm{a}}$ & $+\mathrm{ve}$ & -ve \\
\hline \multirow{3}{*}{$\mathbf{A P}$} & LAP & $3.93 \times 10^{10} \pm 0.21^{\mathrm{b}}$ & $3.56 \times 10^{10} \pm 0.20^{\mathrm{a}}$ & $+\mathrm{ve}$ & -ve \\
\hline & HАР & $4.88 \times 10^{10} \pm 0.21^{\mathrm{a}}$ & $2.83 \times 10^{10} \pm 0.20^{\mathrm{b}}$ & $+\mathrm{ve}$ & -ve \\
\hline & WSH & $6.22 \times 10^{10} \pm 0.26^{\mathrm{a}}$ & $3.80 \times 10^{10} \pm 0.24^{\mathrm{a}}$ & $+\mathrm{ve}$ & -ve \\
\hline \multirow[t]{7}{*}{ LT } & PL & $2.40 \times 10^{10} \pm 0.26^{\mathrm{c}}$ & $3.40 \times 10^{10} \pm 0.24^{\mathrm{a}}$ & -ve & -ve \\
\hline & $\mathbf{S}$ & $4.60 \times 10^{10} \pm 0.26^{\mathrm{b}}$ & $2.40 \times 10^{10} \pm 0.24^{b}$ & $+\mathrm{ve}$ & -ve \\
\hline & 33WKS $\times$ LAP $\times$ WSH & $5.40 \times 10^{10} \pm 0.53^{\mathrm{cd}}$ & $2.90 \times 10^{10} \pm 0.49^{c}$ & -ve & -ve \\
\hline & 33WKS $\times$ LAP $\times \mathbf{P L}$ & $3.20 \times 10^{10} \pm 0.53^{\mathrm{ef}}$ & $1.30 \times 10^{10} \pm 0.49^{\mathrm{f}}$ & +ve & -ve \\
\hline & 33WKS $\times \mathbf{L A P} \times \mathbf{S}$ & $7.10 \times 10^{10} \pm 0.53^{\mathrm{ab}}$ & $4.50 \times 10^{10} \pm 0.49^{b}$ & $+\mathrm{ve}$ & -ve \\
\hline & 33WKS $\times$ HAP $\times W S H$ & $610 \times 10^{10} \pm 0.53^{b c}$ & $3.40 \times 10^{10} \pm 0.49^{\mathrm{bc}}$ & -ve & -ve \\
\hline & $33 W K S \times H A P \times P L$ & $3.70 \times 10^{10} \pm 0.53^{\mathrm{e}}$ & $2.00 \times 10^{10} \pm 0.49^{\mathrm{de}}$ & $+\mathrm{ve}$ & -ve \\
\hline \multirow{7}{*}{$\mathbf{F A} \times \mathbf{A P} \times \mathbf{L T}$} & $33 W K S \times H A P \times S$ & $8.50 \times 10^{10} \pm 0.53^{\mathrm{a}}$ & $6.20 \times 10^{10} \pm 0.49^{a}$ & $+\mathrm{ve}$ & +ve \\
\hline & 43WKS $\times$ LAP $\times W S H$ & $2.90 \times 10^{10} \pm 0.53^{\text {ef }}$ & $1.50 \times 10^{10} \pm 0.49^{\mathrm{ef}}$ & -ve & -ve \\
\hline & 43WKS $\times L A P \times P L$ & $1.60 \times 10^{10} \pm 0.53^{\mathrm{fg}}$ & $1.30 \times 10^{10} \pm 0.49^{\mathrm{f}}$ & -ve & -ve \\
\hline & $43 W K S \times L A P \times S$ & $3.40 \times 10^{10} \pm 0.53^{\mathrm{e}}$ & $1.90 \times 10^{10} \pm 0.49^{\text {def }}$ & $+\mathrm{ve}$ & -ve \\
\hline & 43WKS $\times$ HAP $\times W S H$ & $4.00 \times 10^{10} \pm 0.53^{\mathrm{de}}$ & $1.80 \times 10^{10} \pm 0.49^{\mathrm{ef}}$ & -ve & -ve \\
\hline & 43WKS $\times$ HAP $\times P L$ & $1.10 \times 10^{10} \pm 0.53^{\mathrm{g}}$ & $1.00 \times 10^{9} \pm 0.49^{\mathrm{g}}$ & -ve & -ve \\
\hline & 43WKS $\times$ HAP $\times S$ & $5.90 \times 10^{10} \pm 0.53^{b c}$ & $2.60 \times 10^{10} \pm 0.49^{\mathrm{de}}$ & $+\mathrm{ve}$ & -ve \\
\hline
\end{tabular}

Where; $\mathrm{FA}=$ flock age, $\mathrm{AP}=$ Air pressure and $\mathrm{LT}=$ litter types

\section{Reference}

Avcılar, Ö. V., S. Yalçın, E. E. Onbaşılar and M. S. Ramay (2019). "Comparison of slaughter yields and some meat quality parameters in broilers reared on sepiolite-supplemented wood shavings and rice hulls." Poultry science 98(4): 1678-1683.

Banaszak, M., J. Biesek, J. Bogucka, A. Dankowiakowska, D. Olszewski, B. Bigorowski, M. Grabowicz and M. Adamski (2020). "Impact of aluminosilicates on productivity, carcass traits, meat quality, and jejunum morphology of broiler chickens." Poultry Science 99(12): 7169-7177.

Battula, V., M. Schilling, Y. Vizzier-Thaxton, J. Behrends, J. Williams and T. Schmidt (2008). "The effects of low-atmosphere stunning and deboning time on broiler breast meat quality." Poultry Science 87(6): 1202-1210.

Bianchi, M., M. Petracci and C. Cavani (2006). "The influence of genotype, market live weight, transportation, and holding conditions prior to slaughter on broiler breast meat color." Poultry science 85(1): 123-128.

Bihan-Duval, E. L. (2004). "Genetic variability within and between breeds of poultry technological meat quality." World's Poultry Science Journal 60(3): 331-340.

Boni, I., H. Nurul and I. Noryati (2010). "Comparison of meat quality characteristics between young and spent quails." Int. Food Res. J 17(3): 661-666.
Chang, G., L. Lei, X. Zhang, K. Wang, R. Chen, D. Luan and G. Chen (2010). "Development rule of intramuscular fat content in chicken." Journal of Animal and Veterinary Advances 9(2): 297-298.

Dadgar, S., E. Lee, T. Leer, N. Burlinguette, H. Classen, T. Crowe and P. Shand (2010). "Effect of microclimate temperature during transportation of broiler chickens on quality of the pectoralis major muscle." Poultry science 89(5): 1033-1041.

Díaz, O., L. Rodríguez, A. T. Salvador and A. C. García (2010). "Chemical composition and physico-chemical properties of meat from capons as affected by breed and age." Spanish Journal of Agricultural Research(1): 91-99.

Duncan, D. B. (1955). "Multiple range and multiple F tests." Biometrics 11(1): 1-42.

FAO (1980). "Manual of Food Quality Control. FAO, United Nation, Rome, Italy.".

Gandi, B., S. Muhammad, R. Makama, Z. Aliyu and Y. Ibrahim (2020). "SENSORY EVALUATION AND MICROBIAL STATUS OF MEAT FLOSS FROM WEST AFRICAN DWARF GOATS FED GRADED LEVELS OF BROILER LITTER." Science World Journal 15(3): 139-144.

Garcês, A., S. Afonso, A. Chilundo and C. Jairoce (2013). "Evaluation of different litter materials for broiler production in a hot and humid environment: 1. Litter characteristics and quality." Journal of Applied Poultry Research 22(2): 168-176.

Garcia, R., P. I. Almeida, F. R. Caldara, I. Nääs, D. Pereira, L. Freitas, A. Schwingel, N. Lima and J. Graciano (2010). "Effect of the litter 
material on drinking water quality in broiler production." Brazilian Journal of Poultry Science 12(3): 165-169.

Horsted, K., J. Henning and J. E. Hermansen (2005). "Growth and sensory characteristics of organically reared broilers differing in strain, sex and age at slaughter." Acta Agriculturae Scand Section A 55(4): 149-157.

Horwitz, W. (2000). "Association of Official Analytical Chemists. 2000." Official methods of analysis of the Association of Official Analytical Chemist. Gaithersburg, MD, USA.

Huang, H.-W., H.-M. Lung, B. B. Yang and C.-Y. Wang (2014). "Responses of microorganisms to high hydrostatic pressure processing." Food Control 40: 250-259.

Hunt, J., C. Abeyta and T. Tran (2001). "Isolation of Campylobacter species from food and water." Food and Drug Administration bacteriological analytical manual, 8th ed., revision A/1998. Association of Official Analytical Chemists International, Arlington, Va.[Online.] http://vm. cfsan. fda. gov/ebam/bam-7. html.

ISO (2002). "Horizontal method for enumeration of microorganisms, colony count technique at $30^{\circ} \mathrm{C}$." International Standards Organization, Geneva. .

Karamanlis, X., P. Fortomaris, G. Arsenos, I. Dosis, D. Papaioannou, C. Batzios and A. Kamarianos (2008). "The effect of a natural zeolite (clinoptilolite) on the performance of broiler chickens and the quality of their litter." Asian-Australasian Journal of Animal Sciences 21(11): 1642-1650.

Kers, J. G., F. C. Velkers, E. A. Fischer, G. D. Hermes, D. M. Lamot, J. A. Stegeman and H. Smidt (2019). "Take care of the environment: housing conditions affect the interplay of nutritional interventions and intestinal microbiota in broiler chickens." Animal Microbiome 1(1): 114.

Kirmizibayrak, T., K. Önk, B. Ekiz, H. Yalçintan, A. Yilmaz, K. Yazici and A. Altinel (2011). "Effects of age and sex on meat quality of Turkish Native Geese raised under a free-range system." Kafkas Univ. Vet. Fak. Derg 17(5): 817823.

Kokoszynski, D., Z. Bernacki, K. Steczny, M. Saleh, P. Wasilewski, M. Kotowicz, R. Wasilewski, M. Biegniewska and $K$. Grzonkowska (2016). "Comparison of carcass composition, physicochemical and sensory traits of meat from spent broiler breeders with broilers." Eur Poult Sci 80: 781-793.

Li, K., L. Lemonakis, B. Glover, J. Moritz and C. Shen (2017). "Impact of built-up-litter and commercial antimicrobials on Salmonella and Campylobacter contamination of broiler carcasses processed at a pilot mobile poultry-processing unit." Frontiers in veterinary science 4: 88.
Mead, G. (1987). "Recommendation for a standardized method of sensory analysis for broilers." World's poultry science journal.

Mead, G. (2000). "Prospects for 'competitive exclusion'treatment to control salmonellas and other foodborne pathogens in poultry." The Veterinary Journal 159(2): 111-123.

Meluzzi, A., C. Fabbri, E. Folegatti and F. Sirri (2008). "Effect of less intensive rearing conditions on litter characteristics, growth performance, carcase injuries and meat quality of broilers." British Poultry Science 49(5): 509-515.

Mir, N. A., A. Rafiq, F. Kumar, V. Singh and V. Shukla (2017). "Determinants of broiler chicken meat quality and factors affecting them: a review." Journal of food science and technology 54(10): 2997-3009.

Northcutt, J., M. Berrang, J. Dickens, D. Fletcher and N. Cox (2003). "Effect of broiler age, feed withdrawal, and transportation on levels of coliforms, Campylobacter, Escherichia coli and Salmonella on carcasses before and after immersion chilling." Poultry Science 82(1): 169173.

NRC", N. R. C. (1994). "Nutrient Requirements of Poultry." 9th rev. ed. Nat. Acad. Press. Washington, DC.

Pearson, D. (2006). "Chemical Analysis of Foods." 11th Ed, Publishing Co.,.

Pikul, J., D. E. Leszczynski and F. A. Kummerow (1989). "Evaluation of three modified TBA methods for measuring lipid oxidation in chicken meat." Journal of Agricultural and Food Chemistry 37(5): 1309-1313.

Poltowicz, K. (2012). "Effect of slaughter age on performance and meat quality of slow-growing broiler chickens." Annals of Animal Science 12(4): 621-631.

Połtowicz, K. and J. Doktor (2011). "Effect of freerange raising on performance, carcass attributes and meat quality of broiler chicken." Animal Science Papers \& Reports 29(2).

Pudyszak, K., J. Pomianowski and T. Majewska (2005). "Slaughter value and meat quality of guinea fowl slaughtered at a different age." Food Sci. Technol. Quality (2005) 42: 27-34.

Rossaint, S., S. Klausmann and J. Kreyenschmidt (2015). "Effect of high-oxygen and oxygen-free modified atmosphere packaging on the spoilage process of poultry breast fillets." Poultry science 94(1): 96-103.

Saleeva, I. P., V. S. Lukashenko, A. G. Koshchaev, V. G. Volik and D. Y. Ismailova (2018). "Quality of broiler chicken meat with the use of various methods of growing." Journal of Pharmaceutical Sciences and Research 10(11): 2979-2984.

SAS (2004). SAS Institute/QC 9.1: User's Guide, SAS Institute. 
Simsek, U. G., B. Dalkilic, M. Ciftci, I. H. Cerci and M. Bahsi (2009). "Effects of enriched housing design on broiler performance, welfare, chicken meat composition and serum cholesterol." Acta Veterinaria Brno 78(1): 67-74.

Tablante, N., I. Estevez and E. Russek-Cohen (2003). "Effect of perches and stocking density on tibial dyschondroplasia and bone mineralization as measured by bone ash in broiler chickens." Journal of Applied Poultry Research 12(1): 53-59.

Taherparvar, G., A. Seidavi, L. Asadpour, R. Payan-Carreira, V. Laudadio and V. Tufarelli (2016). "Effect of litter treatment on growth performance, intestinal development, and selected cecum microbiota in broiler chickens." Revista Brasileira de Zootecnia 45(5): 257-264.

Torok, V., R. Hughes, K. Ophel-Keller, M. Ali and R. MacAlpine (2009). "Influence of different litter materials on cecal microbiota colonization in broiler chickens." Poultry science 88(12): 2474-2481.

Uhlířová, L., E. Tůmová, D. Chodová, J. Vlčková, M. Ketta, Z. Volek and V. Skřivanová (2018). "The effect of age, genotype and sex on carcass traits, meat quality and sensory attributes of geese." Asian-Australasian journal of animal sciences 31(3): 421.

Vissers, L. S., H. W. Saatkamp and A. G. O. Lansink (2021). "Analysis of synergies and trade-offs between animal welfare, ammonia emission, particulate matter emission and antibiotic use in Dutch broiler production systems." Agricultural Systems 189: 103070.

Vizzier-Thaxton, Y., K. Christensen, M. Schilling, R. Buhr and J. Thaxton (2010). "A new humane method of stunning broilers using low atmospheric pressure." Journal of Applied Poultry Research 19(4): 341-348.

Williams, Z. and K. Macklin (2013). "Stratification of bacterial concentrations, from upper to lower, in broiler litter." Journal of Applied Poultry Research 22(3): 492-498.

Xu, Y., C. Stark, P. Ferket, C. Williams, S. Auttawong and J. Brake (2015). "Effects of dietary coarsely ground corn and litter type on broiler live performance, litter characteristics, gastrointestinal tract development, apparent ileal digestibility of energy and nitrogen, and intestinal morphology." Poultry Science 94(3): 353-361.

Zhao, X., W. Ren, P. B. Siegel, J. Li, Y. Wang, H. Yin, Y. Zhang, S. Lai, G. Shu and Q. Zhu (2018). "Meat quality characteristics of chickens as influenced by housing system, sex, and genetic line interactions." Italian Journal of Animal Science 17(2): 462-468.

$$
\begin{aligned}
& \text { تأثير عمر القطيع, ضغط الهواء و أنواع الفرشة على خصائص الأبيحة و جودة اللحم فى دجاج كتاكيث التسمين } \\
& \text { حمادة محمد أحمد عكاثة }{ }^{1} \text { - جعفر محمود الجندى2 - أسامه حسن منصور الجارحى } 3 \\
& \text { 2, } 1 \\
& \text { هدفت هذه الدراسة إلى تقييم تأثير عمر القطيع ( القطيع الأصغر عمراً } 33 \text { أسبوع و القطيع الأكبر عمراً } 43 \text { أسبوع), ضغط الهواء لهواء } \\
& \text { خلال فترة التفريخ (منخفض, } 100719 \text { و مرتفع } 101000 \text { باسكال) و نوع الفرشة (نشارة الخشب, البلاستيك و الرمل ) على خصائص الذبيحة } \\
& \text { و جودة اللحم فى كتاكيت التسمين. وإستخدم فى هذه الدراسة عدد } 600 \text { كتكوت(روص } 308 \text { ) ) عمر يوم فاقسة من بيض قطيعين مختلفين فى في }
\end{aligned}
$$

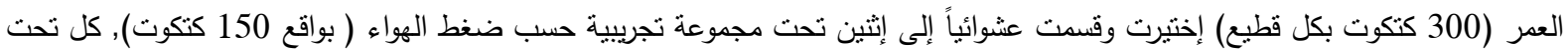

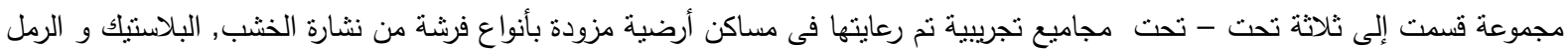

$$
\begin{aligned}
& \text { على الترتيب. صممت هذه الدراسة فى تجربة عاملية 2×2×3 ـ أظهرت النتائج المتحصل عليها أن كتاكيت التسمين المنتجة من القطيع الأكبر } \\
& \text { عمراً سجلت إرتفاعاً معنوياً فى الأوزان النسبية و المطلقة للذبيحة , الأحشاء المأكولة , مجموع الأجزاء المأكولة, نسبة البروتين والرماد, الرائحة, }
\end{aligned}
$$

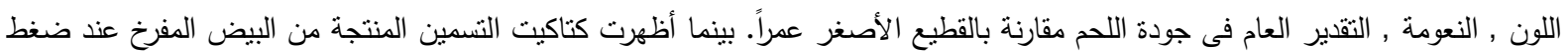

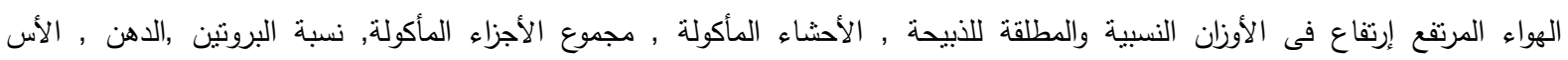

$$
\begin{aligned}
& \text { الهيدروجينى, إجمالى النيتروجين المتطاير , الرائحة فى اللحم. أظهرت كتاكيت التسمين المرباة على الفرشة البلاستيك إرتفاعاً فى قيم الأوزان النسبية } \\
& \text { والمطلقة فى الذبيحة , مجموع الأجزاء المأكولة, نسبة البروتين والرماد, التقيم الحسى للحم و سجلت أقل عدد بكتيرى من أطباق العد البكتبرى فى في } \\
& \text { اللحم والأعورين. بالنسبة للتداخل بين العوامل المدروسة يمكن أن نوصى بأن كتاكيت التسمين الفاقسة من بيض قطيع عند عمر } 43 \text { أسبوع و }
\end{aligned}
$$

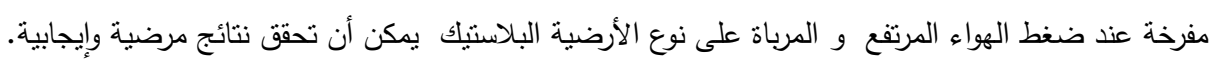

$$
\begin{aligned}
& \text { الكلمات المفتاحية: عمر القطيع , ضعط الهواء , نوع الفرشة , خصائص الذبيحة - جودة اللحم. }
\end{aligned}
$$

